\title{
UPAYA MENINGKATKAN KOMPETENSI GURU DALAM MENYUSUN RENCANA PELAKSANAAN PEMBELAJARAN MELALUI BIMBINGAN BERKELANJUTAN DI SD NEGERI 1 PURWODADI
}

\author{
Lilik Endah Winarti \\ Kepala SD Negeri 1 Purwodadi Kec. Donomulyo Kab. Malang \\ lilik.ewks@gmail.com
}

\begin{abstract}
Some teachers at Purwodadi 1 Elementary School adopted another person's Learning Implementation Plan. This researcher knows when conducting academic supervision (supervision of class visits) to the target schools. These problems have a big influence on the implementation of the learning process. Under these circumstances, researchers as school advisers strive to provide ongoing guidance to teachers in compiling a Learning Implementation Plan in full in accordance with the demands on process standards and assessment standards that are part of the national education standard.

Based on the research conducted, the following results can be obtained: (1) Continuous guidance can increase the motivation of the teacher in compiling a Learning Implementation Plan completely. The teacher shows the seriousness in understanding and compiling the Learning Implementation Plan especially after getting guidance on the development / preparation of the Learning Implementation Plan from the researcher. This information researchers obtained from the results of observations when conducting interviews and guidance development / preparation of Learning Implementation Plans to teachers; and (2) Continuous guidance can improve teacher competence in preparing Learning Implementation Plans. It can be proven from the observation / observation that shows that there is an increase in teacher competency in compiling the Learning Implementation Plan from cycle to cycle. In the first cycle the average value of the components of the Learning Implementation Plan was $69 \%$ and in the second cycle $83 \%$. So, there was a $14 \%$ increase from the first cycle
\end{abstract}

Keyword: Teacher Competence, Learning Implementation Plan, Continuous Guidance

\section{PENDAHULUAN}

Perencanaan pembelajaran merupakan langkah yang sangat penting sebelum pelaksanaan pembelajaran. Perencanaan yang matang diperlukan supaya pelaksanaan pembelajaran berjalan secara efektif. Perencanaan pembelajaran dituangkan ke dalam Rencana Pelaksanaan Pembelajaran (RPP) atau beberapa istilah lain seperti desain pembelajaran, skenario pembelajaran. RPP memuat KD, indikator yang akan dicapai, materi yang akan dipelajari, metode pembelajaran, langkah pembelajaran, media pembelajaran, dan sumber belajar serta penilaian.

Guru harus mampu berperan sebagai desainer (perencana), implementor (pelaksana), dan evaluator (penilai) kegiatan pembelajaran. Guru merupakan faktor yang paling dominan 
karena di tangan gurulah keberhasilan pembelajaran dapat dicapai. Kualitas mengajar guru secara langsung maupun tidak langsung dapat mempengaruhi kualitas pembelajaran pada umumnya. Seorang guru dikatakan profesional apabila (1) serius melaksanakan tugas profesinya, (2) bangga dengan tugas profesinya, (3) selalu menjaga dan berupaya meningkatkan kompetensinya, (4) bekerja dengan sungguh tanpa harus diawasi, (5) menjaga nama baik profesinya, (6) bersyukur atas imbalan yang diperoleh dari profesinya.

Peraturan Pemerintah Nomor 19 Tahun 2005 tentang 8 Standar Nasional Pendidikan menyatakan standar proses merupakan salah satu SNP untuk satuan pendidikan dasar dan menengah yang mencakup: 1) Perencanaan proses pembelajaran, 2) Pelaksanaan proses pembelajaran, 3) Penilaian hasil pembelajaran, 4) dan pengawasan proses pembelajaran. Perencanaan pembelajaran meliputi Silabus dan Rencana Pelaksanaan Pembelajaran (RPP). Silabus dan RPP dikembangkan oleh guru pada satuan pendidikan. Guru pada satuan pendidikan berkewajiban menyusun Silabus dan RPP secara lengkap dan sistematis agar pembelajaran berlangsung secara interaktif, inspiratif, menyenangkan, menantang, memotivasi peserta didik untuk berpartisipasi aktif, serta memberikan ruang yang cukup bagi prakarsa, kreativitas, dan kemandirian sesuai dengan bakat, minat dan perkembangan fisik serta psikologis peserta didik.

Masalah yang terjadi di lapangan masih ditemukan adanya guru (baik di sekolah negeri maupun swasta) yang tidak bisa memperlihatkan RPP yang dibuat dengan alasan ketinggalan di rumah dan bagi guru yang sudah membuat RPP masih ditemukan adanya guru yang belum melengkapi komponen tujuan pembelajaran dan penilaian (soal, skor dan kunci jawaban), serta langkahlangkah kegiatan pembelajarannya masih dangkal. Soal, skor, dan kunci jawaban merupakan satu kesatuan yang tidak dapat dipisahkan. Pada komponen penilaian (penskoran dan kunci jawaban) sebagian besar guru tidak lengkap membuatnya dengan alasan sudah tahu dan ada di kepala. Sedangkan pada komponen tujuan pembelajaran, materi ajar, metode pembelajaran, dan sumber belajar sebagian besar guru sudah membuatnya. Beberapa guru di SD Negeri 1 Purwodadi mengadopsi RPP orang lain. Hal ini peneliti ketahui pada saat mengadakan supervisi akademik (supervisi kunjungan kelas) ke sekolah binaan. Permasalahan tersebut berpengaruh besar terhadap pelaksanaan proses pembelajaran.

Dengan keadaan demikian, peneliti sebagai pembina sekolah berusaha untuk memberi bimbingan berkelanjutan pada guru dalam menyusun RPP secara lengkap sesuai dengan tuntutan pada standar proses dan standar penilaian yang merupakan bagian dari standar nasional pendidikan. Hal itu juga sesuai dengan Tupoksi peneliti sebagai pengawas sekolah berdasarkan Permendiknas No. 12 Tahun 2007 tentang enam standar kompetensi pengawas sekolah yang salah satunya adalah supervisi akademik yaitu membina guru.

Rencana

Pelaksanaan

Pembelajaran harus dibuat agar kegiatan pembelajaran berjalan sistematis dan mencapai tujuan pembelajaran. Tanpa 
Rencana Pelaksanaan Pembelajaran, biasanya pembelajaran menjadi tidak terarah. Oleh karena itu, guru harus mampu menyusun RPP dengan lengkap berdasarkan silabus yang disusunnya. Rencana Pelaksanaan Pembelajaran sangat penting bagi seorang guru karena merupakan acuan dalam melaksanakan proses pembelajaran.

Berdasarkan latar belakang tersebut di atas, maka tujuan Penelitian Tindakan Sekolah (PTS) ini bertujuan untuk meningkatkan kompetensi guru dalam menyusun Rencana Pelaksanaan Pembelajaran melalui bimbingan berkelanjutan di SD Negeri 1 Purwodadi.

\section{METODE PENELITIAN}

\section{A. Tempat Penelitian}

Penelitian Tindakan Sekolah dilaksanakan di salah satu sekolah binaan berstatus swasta yaitu SD Negeri 1 Purwodadi Donomulyo. Pemilihan sekolah tersebut bertujuan untuk meningkatkan kompetensi guru dalam menyusun rencana perlaksanaan pembelajaran (RPP) dengan lengkap.

\section{B. Waktu Penelitian}

Penelitian Tindakan Sekolah (PTS) ini dilaksanakan pada semester satu tahun 2018 selama kurang lebih satu setengah bulan mulai Agustus sampai dengan Oktober 2018.

\section{Rencana Penelitian}

Penelitian Tindakan Sekolah (PTS) ini rencananya dilaksanakan melalui dua siklus untuk melihat peningkatan kompetensi guru dalam menyusun Rencana Pelaksanaan Pembelajaran (RPP).

\section{Siklus I}

1. Peneliti merencanakan tindakan pada siklus I (membuat format/instrumen wawancara, penilaian RPP, rekapitulasi hasil penyusunan RPP)

2. Peneliti memberi kesempatan kepada guru untuk mengemukakan kesulitan atau hambatan dalam menyusun Rencana Pelaksanaan Pembelajaran

3. Peneliti menjelaskan kepada guru tentang pentingnya RPP dibuat secara lengkap

4. Peneliti memberikan bimbingan dalam pengembangan RPP

5. Peneliti melakukan observasi/pengamatan terhadap RPP yang telah dibuat guru

6. Peneliti melakukan revisi atau perbaikan penyusunan rencana pelaksanaan pembelajaran yang lengkap

7. Peneliti dan guru melakukan refleksi

\section{Siklus II}

1. Peneiti merencanakan tindakan pada siklus II yang mendasarkan pada revisi/perbaikan pada siklus I, seperti menugasi guru menyusun RPP yang kedua, mengumpulkan, dan melakukan pembimbingan penyusunan RPP

2. Peneliti melaksanakan tindakan sesuai dengan rencana pada siklus II

3. Peneliti melakukan observasi/pengamatan terhadap RPP yang telah dibuat guru

4. Peneliti melakukan perbaikan atau revisi penyusunan RPP

5. Peneliti dan guru melakukan refleksi

\section{Indikator Pencapaian Hasil}

Peneliti mengharapkan secara rinci indikator pencapaian hasil paling 
rendah $78 \%$ guru membuat kesebelas komponen Rencana Pelaksanaan Pembelajaran sebagai berikut.

1. Komponen identitas mata pelajaran diharapkan ketercapaiannya $100 \%$.

2. Komponen standar kompetensi diharapkan ketercapaiannya $85 \%$.

3. Komponen kompetensi dasar diharapkan ketercapaiannya $85 \%$.

4. Komponen indikator pencapaian kompetensi diharapkan ketercapaiannya $75 \%$.

5. Komponen tujuan pembelajaran diharapkan ketercapaiannya $75 \%$.

6. Komponen materi pembelajaran diharapkan kecercapaian $75 \%$.

7. Komponen alokasi waktu diharapkan ketercapaiannya $75 \%$.

8. Komponen metode pembelajaran diharapkan kecercapaiannya $75 \%$.

9. Komponen langkah-langkah kegiatan pembelajaran diharapkan ketercapaiannya $70 \%$.

10. Komponen sumber belajar diharapkan ketercapaiannya $70 \%$.

11. Komponen penilaian (soal, pedoman penskoran, kunci jawaban) diharapkan ketercapaiannya $75 \%$.

\section{HASIL DAN PEMBAHASAN}

\section{A. Hasil Penelitian}

Dari hasil wawancara terhadap delapan orang guru, peneliti memperoleh informasi bahwa semua guru (delapan orang) belum tahu kerangka penyusunan RPP, hanya sekolah yang memiliki dokumen standar proses (satu buah), hanya dua orang guru yang pernah mengikuti pelatihan pengembangan RPP, umumnya guru mengadopsi dan mengadaptasi RPP, kebanyakan guru tidak tahu dan tidak paham menyusun RPP secara lengkap, mereka setuju bahwa guru harus menggunakan RPP dalam melaksanakan proses pembelajaran yang dapat dijadikan acuan/pedoman dalam proses pembelajaran. Selain itu, kebanyakan guru belum tahu dengan komponen-komponen RPP secara lengkap.

Berdasarkan hasil observasi peneliti terhadap delapan RPP yang dibuat guru (khusus pada siklus I), diperoleh informasi/data bahwa masih ada guru yang tidak melengkapi RPP-nya dengan komponen dan sub-subkomponen RPP tertentu, misalnya komponen indikator dan penilaian hasil belajar (pedoman penskoran dan kunci jawaban). Rumusan kegiatan siswa pada komponen langkah-langkah kegiatan pembelajaran masih kurang tajam, interaktif, inspiratif, menantang, dan sistematis.

\section{Siklus I}

Siklus pertama terdiri dari empat tahap yakni: (1) perencanaan, (2) pelaksanaan, (3) observasi, dan (4) refleksi seperti berikut ini.

1. Perencanaan (Planning)
a. Membuat lembar wawancara
b. Membuat format/instrumen penilaian RPP
c. Membuat format rekapitulasi hasil penyusunan RPP siklus I dan II penyusunan RPP dari siklus ke siklus
d. Membuat format rekapitulasi hasil

2. Pelaksanaan (Acting)

Pada saat awal siklus pertama indikator pencapaian hasil dari setiap komponen RPP belum sesuai/tercapai seperti rencana/keinginan peneliti. Hal itu dibuktikan dengan masih adanya komponen RPP yang belum dibuat oleh guru. Sebelas komponen 
RPP yakni:

1) identitas mata pelajaran, 2) standar kompetensi, 3) kompetensi dasar, 4) indikator pencapaian kompetensi, 5) tujuan pembelajaran, 6) materi ajar, 7) alokasi waktu, 8) metode pembelajaran, 9) langkah-langkah kegiatan pembelajaran, 10) sumber belajar, 11) penilaiaan hasil belajar (soal, pedoman penskoran, dan kunci jawaban).

Observasi dilaksanakan tanggal 31 Agustus 2018, terhadap delapan orang guru. Semuanya menyusun RPP, tapi masih ada guru yang belum melengkapi RPP-nya baik dengan komponen maupun sub-sub komponen RPP tertentu. Satu orang tidak melengkapi RPP-nya dengan komponen indikator pencapaian kompetensi. Untuk komponen penilaian hasil belajar, dapat dikemukakan sebagai berikut:

a. Satu orang tidak melengkapinya dengan teknik dan bentuk instrumen

b. Satu orang tidak melengkapinya dengan teknik, bentuk instumen, soal, pedoman penskoran, dan kunci jawaban

c. Dua orang tidak melengkapinya dengan teknik, pedoman penskoran, dan kunci jawaban

d. Satu orang tidak melengkapinya dengan soal, pedoman penskoran, dan kunci jawaban

e. Satu orang tidak melengkapinya dengan pedoman penskoran dan kunci jawaban. Selanjutnya mereka dibimbing dan disarankan untuk melengkapinya

\section{Siklus II}

Siklus kedua juga terdiri dari empat tahap yakni: (1) perencanaan, (2) pelaksanaan, (3) observasi, dan (4) refleksi.

Observasi dilaksanakan tanggal 21 September 2018, terhadap delapan orang guru. Semuanya menyusun RPP, tapi masih ada guru yang keliru dalam menentukan kegiatan siswa dalam langkah-langkah kegiatan pembelajaran dan metode pembelajaran, serta tidak memilah/ menguraikan materi pembelajaran dalam sub-sub materi. Untuk komponen penilaian hasil belajar, dapat dikemukakan sebagai berikut:

1. Satu orang keliru dalam menentukan teknik dan bentuk instrumennya.

2. Satu orang keliru dalam menentukan bentuk instrumen berdasarkan teknik penilaian yang dipilih

3. Dua orang kurang jelas dalam menentukan pedoman penskoran

4. Satu orang tidak menuliskan rumus perolehan nilai siswa

5. Selanjutnya mereka dibimbing dan disarankan untuk melengkapinya

\section{B. Pembahasan}

Penelitian Tindakan Sekolah dilaksanakan di SD Negeri 1 Purwodadi Donomulyo Kabupaten Malang yang merupakan sekolah binaan peneliti berstatus swasta, terdiri atas delapan guru, dan dilaksanakan dalam dua siklus. Kedelapan guru tersebut menunjukkan sikap yang baik dan termotivasi dalam menyusun RPP dengan lengkap. Hal ini peneliti ketahui dari hasil pengamatan pada saat melakukan wawancara dan bimbingan penyusunan RPP. 
Selanjutnya dilihat dari kompetensi guru dalam menyusun RPP, terjadi peningkatan dari siklus ke siklus.

\section{Komponen Identitas Mata Pelajaran}

Pada siklus pertama semua guru (delapan orang) mencantumkan identitas mata pelajaran dalam RPPnya (melengkapi RPP-nya dengan identitas mata pelajaran). Jika dipersentasekan, 84\%. Lima orang guru mendapat skor 3 (baik) dan tiga orang mendapat skor 4 (sangat baik). Pada siklus kedua kedelapan guru tersebut mencantumkan identitas mata pelajaran dalam RPP-nya. Semuanya mendapat skor 4 (sangat baik). Jika dipersentasekan, 100\%, terjadi peningkatan $16 \%$ dari siklus I.

\section{Komponen Standar Kompetensi}

Pada siklus pertama semua guru (delapan orang) mencantumkan standar kompetensi dalam RPP-nya (melengkapi RPP-nya dengan standar kompetensi). Jika dipersentasekan, $81 \%$. Masing-masing satu orang guru mendapat skor 1, 2, dan 3 (kurang baik, cukup baik, dan baik). Lima orang guru mendapat skor 4 (sangat baik). Pada siklus kedua kedelapan guru tersebut mencantumkan standar kompetensi dalam RPP-nya. Dua orang mendapat skor 3 (baik) dan enam orang mendapat skor 4 (sangat baik). Jika dipersentasekan, 94\%, terjadi peningkatan $13 \%$ dari siklus I.

\section{Komponen Kompetensi Dasar}

Pada siklus pertama semua guru (delapan orang) mencantumkan kompetensi dasar dalam RPP-nya (melengkapi RPP-nya dengan kompetensi dasar). Jika dipersentasekan, 81\%. Satu orang guru masing-masing mendapat skor 1, 2, dan 3 (kurang baik, cukup baik, dan baik). Lima orang guru mendapat skor 4 (sangat baik). Pada siklus kedua kedelapan guru tersebut mencantumkan kompetensi dasar dalam RPP-nya. Dua orang mendapat skor 3 (baik) dan enam orang mendapat skor 4 (sangat baik). Jika dipersentasekan, 94\%, terjadi peningkatan $13 \%$ dari siklus I.

4. Komponen Indikator Pencapaian Kompetensi

Pada siklus pertama tujuh orang guru mencantumkan indikator pencapaian kompetensi dalam RPPnya (melengkapi RPP-nya dengan indikator pencapaian kompetensi). Sedangkan satu orang tidak mencantumkan/melengkapinya. Jika dipersentasekan, 56\%. Dua orang guru masing-masing mendapat skor 1 dan 2 (kurang baik dan cukup baik). Empat orang guru mendapat skor 3 (baik). Pada siklus kedua kedelapan guru tersebut mencantumkan indikator pencapaian kompetensi dalam RPP-nya. Tujuh orang mendapat skor 3 (baik) dan satu orang mendapat skor 4 (sangat baik). Jika dipersentasekan, 78\%, terjadi peningkatan $22 \%$ dari siklus I.

\section{Komponen Tujuan Pembelajaran}

Pada siklus pertama semua guru (delapan orang) mencantumkan tujuan pembelajaran dalam RPP-nya (melengkapi RPP-nya dengan tujuan pembelajaran). Jika dipersentasekan, $63 \%$. Satu orang guru mendapat skor 1 (kurang baik), dua orang mendapat skor 2 (cukup baik), dan lima orang mendapat skor 3 (baik). Pada siklus 
kedua kedelapan guru tersebut mencantumkan tujuan pembelajaran dalam RPP-nya. Lima orang mendapat skor 3 (baik) dan tiga orang mendapat skor 4 (sangat baik). Jika dipersentasekan, 84\%, terjadi peningkatan $21 \%$ dari siklus I.

\section{Komponen Materi Ajar}

Pada siklus pertama semua guru (delapan orang) mencantumkan materi ajar dalam RPP-nya (melengkapi RPP-nya dengan materi ajar). Jika dipersentasekan, $66 \%$. Satu orang guru masing-masing mendapat skor 1 dan 4 (kurang baik dan sangat baik), dua orang mendapat skor 2 (cukup baik), dan empat orang mendapat skor 3 (baik). Pada siklus kedua kedelapan guru tersebut mencantumkan materi ajar dalam RPP-nya. Enam orang mendapat skor 3 (baik) dan dua orang mendapat skor 4 (sangat baik). Jika dipersentasekan, $81 \%$, terjadi peningkatan $15 \%$ dari siklus I.

\section{Komponen Alokasi Waktu}

Pada siklus pertama semua guru (delapan orang) mencantumkan alokasi waktu dalam RPP-nya (melengkapi RPP-nya dengan alokasi waktu). Semuanya mendapat skor 3 (baik). Jika dipersentasekan, 75\%. Pada siklus kedua kedelapan guru tersebut mencantumkan alokasi waktu dalam RPP-nya. Tiga orang mendapat skor 3 (baik) dan lima orang mendapat skor 4 (sangat baik). Jika dipersentasekan, 91\%, terjadi peningkatan $16 \%$ dari siklus I.

\section{Komponen Metode Pembelajaran}

Pada siklus pertama semua guru (delapan orang) mencantumkan metode pembelajaran dalam RPP-nya (melengkapi RPP-nya dengan metode pembelajaran). Jika dipersentasekan, 72\%. Dua orang guru mendapat skor 2 (cukup baik), lima orang mendapat skor 3 (baik), dan satu orang mendapat skor 4 (sangat baik). Pada siklus kedua kedelapan guru tersebut mencantumkan metode pembelajaran dalam RPP-nya. Satu orang mendapat skor 2 (cukup baik), enam orang mendapat skor 3 (baik), dan satu orang mendapat skor 4 (sangat baik). Jika dipersentasekan, 75\%, terjadi peningkatan 3\% dari siklus I.

\section{Komponen Langkah-Langkah Kegiatan Pembelajaran}

Pada siklus pertama semua guru (delapan orang) mencantumkan langkah-langkah kegiatan pembelajaran dalam RPP-nya (melengkapi RPP-nya dengan langkah-langkah kegiatan pembelajaran). Jika dipersentasekan, $53 \%$. Tujuh orang guru mendapat skor 2 (cukup baik), sedangkan satu orang mendapat skor 3 (baik). Pada siklus kedua kedelapan guru tersebut mencantumkan langkah-langkah kegiatan pembelajaran dalam RPPnya. Satu orang mendapat skor 2 (cukup baik) dan tujuh orang mendapat skor 3 (baik). Jika dipersentasekan, $72 \%$, terjadi peningkatan $19 \%$ dari siklus I.

\section{Komponen Sumber Belajar}

Pada siklus pertama semua guru (delapan orang) mencantumkan sumber belajar dalam RPP-nya (melengkapi RPP-nya dengan sumber belajar). Jika dipersentasekan, 66\%. Tiga orang guru mendapat skor 2 (cukup baik), 
sedangkan lima orang mendapat skor 3 (baik). Pada siklus kedua kedelapan guru tersebut mencantumkan sumber belajar dalam RPP-nya. Dua orang mendapat skor 2 (cukup baik) dan enam orang mendapat skor 3 (baik). Jika dipersentasekan, 69\%, terjadi peningkatan 3\% dari siklus I.

\section{Komponen Penilaian Hasil Belajar}

Pada siklus pertama semua guru (delapan orang) mencantumkan penilaian hasil belajar dalam RPPnya meskipun sub-sub komponennya (teknik, bentuk instrumen, soal), pedoman penskoran, dan kunci jawabannya kurang lengkap. Jika dipersentasekan, 56\%. Dua orang guru masing-masing mendapat skor 1 dan 3 (kurang baik dan baik), tiga orang mendapat skor 2 (cukup baik), dan satu orang mendapat skor 4 (sangat baik). Pada siklus kedua kedelapan guru tersebut mencantumkan penilaian hasil belajar dalam RPP-nya meskipun ada guru yang masih keliru dalam menentukan teknik dan bentuk penilaiannya. Tujuh orang mendapat skor 3 (baik) dan satu orang mendapat skor 4 (sangat baik). Jika dipersentasekan, $78 \%$, terjadi peningkatan $22 \%$ dari siklus I.

Berdasarkan pembahasan di atas terjadi peningkatan kompetensi guru dalam menyusun RPP. Pada siklus I nilai rata-rata komponen RPP 69\%, pada siklus II nilai rata-rata komponen RPP $83 \%$, terjadi peningkatan $14 \%$.

\section{SIMPULAN DAN SARAN}

\section{A. Simpulan}

Berdasarkan hasil Penelitian Tinadakan Sekolah (PTS) dapat disimpulkan sebagai berikut:

1. Bimbingan berkelanjutan dapat meningkatkan motivasi guru dalam menyusun RPP dengan lengkap. Guru menunjukkan keseriusan dalam memahami dan menyusun RPP apalagi setelah mendapatkan bimbingan

pengembangan/penyusunan RPP dari peneliti. Informasi ini peneliti peroleh dari hasil pengamatan pada saat mengadakan wawancara dan bimbingan

pengembangan/penyusunan RPP kepada para guru

2. Bimbingan berkelanjutan dapat meningkatkan kompetensi guru dalam menyusun RPP. Hal itu dapat dibuktikan dari hasil observasi /pengamatan yang memperlihatkan bahwa terjadi peningkatan kompetensi guru dalam menyusun RPP dari siklus ke siklus. Pada siklus I nilai rata-rata komponen RPP 69\% dan pada siklus II 83\%. Jadi, terjadi peningkatan $14 \%$ dari siklus I

\section{B. Saran}

Telah terbukti bahwa dengan bimbingan berkelanjutan dapat meningkatkan motivasi dan kompetensi guru dalam menyusun RPP. Oleh karena itu, peneliti menyampaikan beberapa saran sebagai berikut.

1. Motivasi yang sudah tertanam khususnya dalam penyusunan RPP hendaknya terus dipertahankan dan ditingkatkan/ dikembangkan. 
2. RPP yang disusun/dibuat hendaknya mengandung komponen-komponen RPP secara lengkap dan baik karena RPP merupakan acuan/pedoman dalam melaksanakan pembelajaran.

3. Dokumen RPP hendaknya dibuat minimal dua rangkap, satu untuk arsip sekolah dan satunya lagi untuk pegangan guru dalam melaksanakan proses pembelajaran.

\section{DAFTAR PUSTAKA}

Daradjat, Zakiyah. 1980. Kepribadian Guru. Jakarta: Bulan Bintang

Dewi, Kurniawati Eni. 2009. Pengembangan Bahan Ajar Bahasa Dan Sastra Indonesia Dengan Pendekatan Tematis. Tesis. Surakarta: Program Pascasarjana Universitas Sebelas Maret

Depdiknas. 2003. UU RI No. 20 Tahun 2003 tentang Sistem Pendidikan Nasional. Jakarta: Depdiknas.
Imron, Ali. 2000. Pembinaan Guru Di Indonesia. Malang: Pustaka Jaya

Kemendiknas. 2018. Penelitian Tindakan Sekolah. Jakarta

Nawawi, Hadari. 1985. Metode Penelitian Bidang Sosial. Yogyakarta: Gadjah Mada University Press.

Nurhadi. 2004. Kurikulum 2004. Jakarta: PT Gramedia Widiasarana Indonesia

Pidarta, Made. 1992. Pemikiran Tentang Supervisi Pendidikan. Jakarta: Bumi Aksara

Sudjana, Nana. 2009. Standar Kompetensi Pengawas Dimensi dan Indikator. Jakarta: Binamitra Publishing Suharjono. 2003. Menyusun Usulan Penelitian. Jakarta: Makalah Disajikan pada Kegiatan Pelatihan Tehnis Tenaga Fungsional Pengawas

Suparlan. 2005. Menjadi Guru Efektif. Yogyakarta: Hikayat Publishing. 